\title{
Application of machine learning for development of a drying protocol for microalga Chlorella minutissima in a single rotary drum dryer for biodiesel production
}

\author{
SASHI SONKAR ${ }^{1}$, Shibani . ${ }^{2}$, and Nirupama Mallick ${ }^{1}$ \\ ${ }^{1}$ Indian Institute of Technology Kharagpur \\ ${ }^{2}$ Birla Institute of Technology and Science Pilani
}

October 26, 2020

\begin{abstract}
Drying of microalgal slurry is one of the important steps of downstream processing which faces several technical challenges for cost-effective biodiesel production. In this investigation, drying of C. minutissima was carried out by a single rotary drum dryer with varied drum surface temperature and rotational speed. Application of machine learning tool classified the range of residual moisture content to be $<10 \%$ (wet biomass) for high lipid recovery with an accuracy of $97 \%$. Based on the drying time, lipid recovery, and energy consumption, drum drying at $80{ }^{\circ} \mathrm{C}$ drum surface temperature with $0.3 \mathrm{rpm}$ depicted $i 90 \%$ lipid recovery as compared to the bone-dried biomass. The energy consumption of $7.328 \mathrm{kWh}$ for $1 \mathrm{~kg}$ of dried biomass was recorded with profoundly lower drying time, thus could be recommended for drying of the microalgal slurry at industrial scale.
\end{abstract}

\section{INTRODUCTION}

Microalgal biodiesel promises to be a zero $\mathrm{CO}_{2}$-emitting and renewable energy source. The biodiesel production from microalgae includes various steps beginning from cultivation of the desired strain followed by harvesting, drying of microalgal slurry, oil extraction from the biomass, and transesterification of lipid to biodiesel (O'Connell, Savelski, \& Slater, 2013). However, the downstream processing of the harvested microalgal slurry faces several technical challenges for cost-effective biodiesel production. Drying of microalgal biomass is one of those important steps. Dewatering of the harvested microalgal slurry is essential to enhance the viability of biomass for lipid extraction, and also to reduce the costs of handling, transportation, packaging, and storage (Bennamoun, Arlabosse, \& Léonard, 2013).

Many drying techniques are available nowadays which include advanced techniques like spray drying, tray drying, oven drying, freeze drying, vacuum-shelf drying, cross-flow air drying, etc, as well as the simple and natural solar drying. The suitability of a method depends on many factors such as the properties and types of the microalgal suspension, the downstream processes, the end product type and quality, and the overall cost of production (Chen, Chang, \& Lee, 2015). The drying techniques such as freeze drying (Guldhe, Singh, Rawat, Ramluckan, \& Bux, 2014), thin layer drying (Hosseinizand, Sokhansanj, \& Lim, 2018), microwave drying (Villagracia et al., 2016) etc. are mainly used at a laboratory-scale, whereas drum drying technique could be useful at industrial level for drying of large-scale microalgal slurry.

The major advantages of drying the microalgal slurry in a drum dryer are breaking the cell wall and sterilization of the dried biomass (Show, Lee, \& Mujumdar, 2015). Mahadevaswamy \& Venkataraman (1981) reported that drum drying of Scenedesmus acutus 273-3a biomass for a detention time of 8-10 sec reduced the microbial load during storage. An electrically-heated drum dryer was tested for drying ofScenedesmus sp. biomass containing $70 \%$ moisture for $10 \mathrm{sec}$ at $120{ }^{\circ} \mathrm{C}$ and the energy consumption was calculated to be 
$52 \mathrm{kWh}$ (Becker \& Venkataraman, 1982). A steam-heated drum drying of Spirulinaslurry was carried out at $120-128{ }^{\circ} \mathrm{C}$ for $16 \mathrm{sec}$ for preparing the feed for aquaculture (Sethi \& Naik, 2007). Recently, Wahlen et al. (2017), used a bench-scale rotary drum dryer for drying the Scenedesmussp. at $50{ }^{\circ} \mathrm{C}$. Thus, for faster drying, a drum dryer could be a suitable option for large-scale processing of microalgal slurry.

Machine learning, on the otherhand is a new edge technology used in every sector of research. It can be divided into two segments, i.e. supervised learning and unsupervised learning. Supervised learning is implemented when a structured data set is provided and we know what our output would look like. Whereas, unsupervised learning allows us to tackle the problem with little or no knowledge of what our results would be. It is further divided as shown in the Figure 1.

There are different algorithms to implement the mentioned modules (Figure 1). Regression can be done using linear regression algorithm and classification using logistic regression or simple vector machine. Algorithms like neural networks can be used for both. Unsupervised learning can be done through K-mean or principal component analysis.

For our defined problem, we have taken the supervised-classification module into consideration to label the outputs good or poor. Out of logistic regression and simple vector machine, logistic regression is employed based on the fact that we have a large number of features compared to training examples. Here, there was a chance for overfitting of the decision boundary for which regularization was also executed. Logistic regression is a predictive algorithm. The present investigation is thus, aimed at developing a microalgal drying protocol at different drum surface temperature with varying drum speed using the logistic regression with regularization to obtain maximum lipid from microalgal biomass for biodiesel purpose.

\section{MATERIALS AND METHODS}

\subsection{Culture conditions for the experimental organism}

Chlorella minutissima, a fast-growing green microalga, was selected for this study. Axenic cultures of the test microalga was maintained in Erlenmeyer flasks with N 11 medium as per Soeder \& Bolze (1981). The temperature was mentained at $25 \pm 2{ }^{\circ} \mathrm{C}$ with phtoperiod of $14 \mathrm{~h}$ and light intensity of $75 \mu \mathrm{mol}$ photons m ${ }^{-2} \mathrm{~s}^{-1}$ PAR.

For drying experiments, C. minutissima was cultivated in raceway ponds with volumetric capacity of 40,000 L each $(14 \times 4 \times 0.75 \mathrm{~m})$. Before cultivation in raceway ponds, the selected microalga was scaled-up in the UZn medium (Koley, Mathimani, Bagchi, Sonkar, \& Mallick, 2019), and was acclimatized to the outdoor condition as detailed in Sonkar, Deb, \& Mallick (2020). The raceway ponds were operated at $30 \mathrm{~cm}$ of culture depth with a corresponding culture volume of $16000 \mathrm{~L}$. Harvesting of the microalgal biomass was carried by pH-induced flocculation using $\mathrm{NaOH}$ at pH 12 for 12 h following Koley, Prasad, Bagchi, \& Mallick (2017).

\subsection{Drying experiments in a single rotary drum dryer}

Drum drying is a continuous indirect heating process. A single rotary drum dryer consisting of a hollow cylinder made up of stainless steel was mounted horizontally on a supporting frame and rotated continuously. The speed of the drum could be regulated by a variable-speed drive. The diameter and length of the cylindrical drum were 48.5 and $45.2 \mathrm{~cm}$, respectively. During the operation, thermal oil filled in the storage tank was heated up to $100 \pm 2{ }^{\circ} \mathrm{C}$ which was pumped into the hollow cylindrical drum for heating. The closed system of the drum did not allow the sample to be in contact with the oil, but provided uniform temperature distribution over the drum surface, which ensrured consistent product quality.

The microalgal slurry was uniformly attached to the drum surface from the algal reservoir through continuous rotation. The heated drum slowly dried the wet microalgal slurry on the outside of the drum surface and was finally scrapped by the doctor blade (scraper device). The exposure of the microalgal slurry to a high temperature for a short period reduces the risk of damage to the dried-biomass. The residence time of the product on the drum surface depends upon the speed of the drum ranging from 0.1 revolution per minute (rpm) to several rpm. In the present investigation, the microalgal slurry was dried at varying drying 
temperature from $70,80,90$, and $100{ }^{\circ} \mathrm{C}$ at eight different rpm, i.e., $0.1,0.2,0.3,0.4,0.5,1.0,1.5$, and 2.0 rpm.

\subsection{Estimation of moisture content}

The moisture content was determined by the following formula (Chakraverty, 1988):

$$
M C=\frac{W_{m} \times 100}{\left(W_{\mathrm{m}}+\mathrm{W}_{d}\right)}
$$

Where,

MC: Moisture content (\%) in wet basis (wb)

$\mathrm{W}_{\mathrm{m}}$ : Weight of moisture in the biomass

$\mathrm{W}_{\mathrm{d}}$ : Weight of bone-dried biomass

(bone drying referred to oven drying of the biomass at $103 \pm 2{ }^{\circ} \mathrm{C}$ for $24 \mathrm{~h}$, Chakraverty, 1988).

\subsection{Extraction and estimation of lipids}

The standard protocol of Bligh \& Dyer (1959) was followed for lipid extraction from the drum dried microalgal biomass with chloroform, methanol and distilled water as solvents. The organic layer was evaporated in a water bath followed by drying at $104{ }^{\circ} \mathrm{C}$ for $30 \mathrm{~min}$. The weight of the lipid was estimated in a high precsion balace of Sartorious, Germanny.

\subsection{Application of machine learning}

There were four factors in these experiments, namely, drum speed (rpm), drum surface temperature $\left({ }^{\circ} \mathrm{C}\right)$, residual moisture content (\% wb) and lipid yield ( $\mathrm{mg} \mathrm{g}^{-1}$ of dry biomass). Residual moisture content and lipid yield of corresponding drum speed and drum temperature were mapped to get two features. The training data sets were labelled good (1) or poor (2) based on the lipid yield and residual moisture content (Table 1). Logistic regression with regularisation was used to do the classification of the data gathered through experiments (Dreiseitl \& Ohno-Machado, 2002). The following steps mentioned in the Figure 2 were employed.

\subsection{Estimation of energy consumption}

The energy consumption in the single rotary drum dryer was calculated by a digital clamp multimeter (Model: Metravi-107, Metravi Instruments Pvt. Ltd., West Bengal, India). It records the AC/DC voltage in the range of 0.0-599.9 $\mathrm{V}$ with a resolution of $0.1 \mathrm{~V}$ and current in the range of 0.0-399.0 $\mathrm{A}$ with a resolution of $0.1 \mathrm{~A}$. The accuracy was $\pm 5 \%$ for both, $\mathrm{AC} / \mathrm{DC}$ voltage and current.

\subsection{Statistical analysis}

One-way and two-way ANOVA (Analysis of Variance) with Duncan's new multiple range test were used for revealing the significance of the data with the help of IBM SPSS version 22 statistical software (Chicago, Illinois, USA). The experiments were conducted in triplicate and repeated thrice for validation of the study.

\section{RESULTS AND DISCUSSION}

\subsection{Bone drying of C. minutissima slurry}

The microalgal slurry was taken in glass vials and kept for drying in a laboratory-scale oven at $103 \pm 2{ }^{\circ} \mathrm{C}$ for $24 \mathrm{~h}$. This was referred to be bone drying materials. The moisture content of the microalgal slurry was found to be $\sim 90 \%$ of the wet biomass (wb). The lipid yield of the bone-dried samples was recorded to be $142.1 \pm 4.1 \mathrm{mg} \mathrm{g}^{-1}$ of dry biomass, whereas for the biomass slurry dried at $60 \pm 2{ }^{\circ} \mathrm{C}$ till to reach constant weight following Rai, Mallick, Singh, \& Kumar (1991) in the same laboratory-scale oven was $146.3 \pm 3.2 \mathrm{mg}$ $\mathrm{g}^{-1}$ of dry biomass (Table 2). These observations revealed that there was insignificant variation in lipid yield 
between the bone-dried and the biomass obtained by drying at $60{ }^{\circ} \mathrm{C}$, although the biomass yield varied significantly under both the conditions.

\subsection{Drum drying at different temperature with variable speed}

Drum speed and surface temperature of the drum are the two major variables that affect the residual moisture content of the dried algal biomass. The residual moisture content of the microalgal slurry was found to be reduced maximum up to $41.4 \pm 2.7 \%$ (wb) under the drum speed of $0.1 \mathrm{rpm}$ at drum surface temperature of $70{ }^{\circ} \mathrm{C}$ (Figure $3 \mathrm{~A}$ ). By increasing the drum surface temperature to $80{ }^{\circ} \mathrm{C}$, the residual moisture content of the microalgal slurry was reduced to $<10 \%$ (wb) under the drum speed of $0.1,0.2$, and $0.3 \mathrm{rpm}$ (Figure $4 \mathrm{~A}$ ). Likewise, at $90{ }^{\circ} \mathrm{C}$ of drum surface temperature, the residual moisture content was reduced up to $4.6 \pm 1.1$, $5.3 \pm 1.3,6.1 \pm 1.5$, and $7.3 \pm 2.6 \%(\mathrm{wb})$ at $0.1,0.2,0.3$, and $0.4 \mathrm{rpm}$, respectively (Figure 5A). Further, at $100{ }^{\circ} \mathrm{C}$ of drum surface temperature, the residual moisture content was $3.5 \pm 1.7,3.9 \pm 1.5,4.4 \pm 2.3,6.3$ \pm 1.6 , and $7.1 \pm 2.1 \%(\mathrm{wb})$, respectively, for the drum speed of $0.1,0.2,0.3,0.4$, and $0.5 \mathrm{rpm}$ (Figure $6 \mathrm{~A}$ ). From Duncan's new multiple range test analysis, it can be concluded that there was no significant variation in the residual moisture content of the drum-dried biomass at $80{ }^{\circ} \mathrm{C}$ with drum speed of $0.1-0.3 \mathrm{rpm}, 90{ }^{\circ} \mathrm{C}$ with drum speed of 0.1-0.4 rpm, and $100{ }^{\circ} \mathrm{C}$ with drum speed of 0.1-0.5 rpm (Table 3).

The summary of lipid yield ( $\mathrm{mg} \mathrm{g}^{-1}$ of dry biomass) and lipid recovery (\%) at different drum surface temperature under varying drum speed is presented in Table 4 . The maximum lipid yield was found to be $72.1 \pm$ $5.2 \mathrm{mg} \mathrm{g}^{-1}$ of dry biomass with the corresponding lipid recovery of $50.7 \%$ only as compared to the bone-dried samples under the drum speed of $0.1 \mathrm{rpm}$ at $70{ }^{\circ} \mathrm{C}$ of drum surface temperature (Figure 3B, C). This is well in agreement with the report of Balasubramanian, Doan, \& Obbard (2013), where a significant reduction in lipid extraction efficiency was evident from the biomass of Nannochloropsis sp. with higher moisture content. The possible reason could be that the hydrophilic outer layer of the microalgal cell wall was surrounded by water molecules that resist the non-polar solvent penetrating inside the cell and hinders the extraction of lipids (Balasubramanian et al., 2013). At the drum surface temperature of $80{ }^{\circ} \mathrm{C}$, the lipid yield was estimated to be ranged between 130.6-131.3 $\mathrm{mg} \mathrm{g}^{-1}$ of dry biomass at the drum speed of 0.1-0.3 rpm, and the maximum lipid yield of $131.3 \pm 3.1 \mathrm{mg} \mathrm{g}^{-1}$ of dry biomass with lipid recovery of $92.4 \%$ was obtained at $0.3 \mathrm{rpm}$ (Figure 4B, C). Similarly, the lipid yield was found to be in the range of $130.2-132.2 \mathrm{mg} \mathrm{g}^{-1}$ of dry biomass with 0.1-0.3 rpm at the drum surface temperature of $90{ }^{\circ} \mathrm{C}$. The maximum lipid yield of $132.2 \pm$ $3.4 \mathrm{mg} \mathrm{g}^{-1}$ dry biomass was obtained under the drum speed of $0.4 \mathrm{rpm}$ at $90{ }^{\circ} \mathrm{C}$ with the corresponding lipid recovery of $93 \%$ as compared to the bone-dried samples (Figure 5B, C). Likewise, at $100{ }^{\circ} \mathrm{C}$ of drum surface temperature, the maximum lipid yield was found to be in the range of $127.5-133.3 \mathrm{mg} \mathrm{g}^{-1}$ of dry biomass between 0.1-0.5 rpm; the maximum lipid yield was estimated to be $133.3 \pm 5.4 \mathrm{mg}$ g- 1 of dry biomass under $0.5 \mathrm{rpm}$ with the corresponding lipid recovery of $93.8 \%$ at drum surface temperature of $100{ }^{\circ} \mathrm{C}$ (Figure $6 \mathrm{~B}$, C). From Duncan's new multiple range test analysis, no significant variation was observed in the lipid yield of the drum-dried biomass at $80{ }^{\circ} \mathrm{C}$ from $0.1-0.3 \mathrm{rpm}, 90{ }^{\circ} \mathrm{C}$ from $0.1-0.4 \mathrm{rpm}$, and $100{ }^{\circ} \mathrm{C}$ from $0.1-0.5 \mathrm{rpm}$ (Table 4). From this observation, drum surface temperature of 80,90 , and $100{ }^{\circ} \mathrm{C}$ with the drum speed of 0.1-0.3, 0.1-0.4, and 0.1-0.5 rpm, respectively, could be selected for maximum lipid recovery from the algal biomass. Zepka, Jacob-Lopes, Goldbeck, \& Queiroz (2008) reported that the constituents of biomass such as lipid, carbohydrate, and protein contents could alter significantly based on the drying temperature. A study revealed that Chlorella vulgaris biomass dried at $60{ }^{\circ} \mathrm{C}$ in an oven resulted in a slight reduction of lipid content, whereas at $80{ }^{\circ} \mathrm{C}$ or much higher temperature, the lipid content was considerably decreased (Widjaja, Chien, \& Ju, 2009). The study cited the possible explanation for the low triacylglycerol yield as oxidation of fatty acid upon exposure to the higher temperature. Contrary to this, the present study showed that drying the microalgal slurry from $80-100{ }^{\circ} \mathrm{C}$ in a drum dryer has insignificant impact on lipid recovery. The probable explanation could be the short duration of exposure of the wet microalgal slurry to a high temperature that reduces the risk of damage to the dried-biomass and its constituents.

\subsection{Identification of decision boundary by machine learning}

Figure 7 shows the distribution of raw date set and identification of the decision boundary respectively for which the above data sets are desirable. This method can be further used to predict whether the testing 
data set should be termed good or poor (Bera, Saha, \& Bhattacharjee, 2020). Logistic regression with regularisation gave the best output in classifying our experimental results (Shi, Li, Ding, \& Gao, 2020). A lot of trails were done to set the values of regularisation constant as 1 and degree of feature mapping as 12 . A decision boundary curve was plotted which divided the X-Y plane into two parts, one being the good yield region and the other poor (Figure. 7B). The data points represented as "X" were termed as good yield and "O" as poor yield. It is evident from the graph that as the moisture content increases the lipid yield reduces. There is an increase in lipid yield when residual moisture content is reduced, drum temperature is increased and drum speed is reduced. This classification helps us in determining the range of the above mentioned factors in which one can get high lipid yield. The plot has an accuracy of $97.037 \%$ and corroborates our observation that a moisture content of $<10 \%$ (wb) would result lipid recovery $>90 \%$ of the bone-dried biomass (Figure 7B).

\subsection{Energy consumption for drum drying}

In this investigation, a comparative evaluation of energy consumption for drum-dried biomass at 80, 90, and $100{ }^{\circ} \mathrm{C}$ of drum surface temperature with varying drum speed was thoroughly conducted. The energy consumption of the drum dryer used in this study for drying $1 \mathrm{~kg}$ of biomass at $80{ }^{\circ} \mathrm{C}$ for $0.3 \mathrm{rpm}$ was 7.328 $\mathrm{kWh}$. By decreasing the rotational speed of the drum, the time required for obtaining $1 \mathrm{~kg}$ of dried biomass increased, which resulted in greater energy consumption. At $90{ }^{\circ} \mathrm{C}$, the energy consumption was $8.4 \mathrm{kWh} / \mathrm{kg}$ dry biomass for $0.4 \mathrm{rpm}$, whereas it was $9.511 \mathrm{kWh} / \mathrm{kg}$ dry biomass at $100{ }^{\circ} \mathrm{C}$ for $0.5 \mathrm{rpm}$. Thus, considering the lipid recovery above $90 \%$ of the bone-dried materials, the minimum energy consumption to get $1 \mathrm{~kg}$ of dried biomass was at $80{ }^{\circ} \mathrm{C}$ for $0.3 \mathrm{rpm}$ followed by $90{ }^{\circ} \mathrm{C}$ for $0.4 \mathrm{rpm}$ and $100{ }^{\circ} \mathrm{C}$ for $0.5 \mathrm{rpm}$ amongst all the other conditions (Table 5). Moreover, the difference in the time consumption for drying $1 \mathrm{~kg}$ of biomass at $80{ }^{\circ} \mathrm{C}$ for $0.3 \mathrm{rpm}$ as compared to $90{ }^{\circ} \mathrm{C}$ for $0.4 \mathrm{rpm}$ and $100{ }^{\circ} \mathrm{C}$ for $0.5 \mathrm{rpm}$ was found to be marginal. Thus, considering the lipid recovery, energy consumption, and time required to obtain $1 \mathrm{~kg}$ of dried biomass, drum surface temperature of $80{ }^{\circ} \mathrm{C}$ with drum speed of $0.3 \mathrm{rpm}$ can be concluded to be the best fit for large-scale drying of the harvested algal biomass in a single rotary drum dryer.

A study conducted by Bagchi, Rao, \& Mallick (2015) revealed thatScenedesmus sp. biomass dried at 80 ${ }^{\circ} \mathrm{C}$ in a laboratory-scale hot air oven recorded an energy consumption of $5.231 \mathrm{kWh} / \mathrm{kg}$ of dry biomass, whereas it was $11.227 \mathrm{kWh} / \mathrm{kg}$ of dry biomass at $80{ }^{\circ} \mathrm{C}$ in a tray dryer with lipid recovery of $>90 \%$ as compared to the bone-dried biomass (Bagchi, 2017). A significant reduction in drying time was observed in drum drying as compared to oven drying and tray drying (Table 6). The lipid recovery with the drum-dried biomass was at par with oven- and tray-dried biomass. The energy consumption was found to be $40 \%$ higher in drum drying as compared to oven drying. However, as compared to tray drying, energy consumption was reduced by $35 \%$ for $1 \mathrm{~kg}$ of dried biomass. Moreover, a profound reduction in drying time was evident with drum drying. Therefore, considering the drying time, lipid recovery, and energy consumption, the drum dryer carries immense potential and could be recommended for drying microalgal slurry at an industrial scale.

\section{CONCLUSION}

Machine learning algorithms provide an ease for identifying patterns. If used with precision, this tool can give incredible outputs. The plot demonstrates an inverse relationship between lipid yield and residual moisture content for corresponding drum temperature and speed. This classification determines the range of residual moisture content to be $<10 \%$ (wb) for high lipid recovery with an accuracy of $97 \%$. Further predictions of any new data set can be done based on this algorithm. In future, linear regression method can also be implemented to get lipid yield value based on moisture content or may be using drum temperature and speed.

\section{ACKNOWLEDGEMENTS}

Dr. Sashi Sonkar gratefully acknowledges UGC-RGNF Scheme, New Delhi, India for fellowship. The authors are thankful to NASF, Indian Council of Agricultural Research, New Delhi, India, for financial support. The authors also acknowledge Prof. S. P. Adhikary, Vice-Chancellor, Fakir Mohan University, Odisha, India for the identification of the test microalga. 


\section{REFERENCES}

Bagchi, S.K. (2017). Production of biodiesel from a locally isolated chlorophycean microalga Scenedesmus obliquus (Turpin) Kützing . [Doctoral disseratation, Agricultural \& Food Engineering Department, Indian Institute of Technology Kharagpur, West Bengal, India]. IIT Kharagpur Campus Repository. http://www.idr.iitkgp.ac.in/xmlui/handle/123456789/8255.

Bagchi, S.K., Rao, P.S., \& Mallick, N. (2015). Development of an oven drying protocol to improve biodiesel production for an indigenous chlorophycean microalga Scenedesmus sp. Bioresource Technology, 180, 207213.

Balasubramanian, R.K., Doan, T.T.Y., \& Obbard, J.P. (2013). Factors affecting cellular lipid extraction from marine microalgae. Chemical Engineering Journal , 215-216, 929-936.

Becker, E.W. (1994). Large-scale cultivation. In E. W. Becker (Ed.),Microalgae: Biotechnology and Microbiology (pp. 63-171). Cambridge University Press.

Becker, E.W. \& Venkataraman, L.V. (1982). Biotechnology and Exploitation of Algae - The Indian Approach . Agency for Technical Cooperation, Eschlorm, Germany.

Bennamoun, L., Arlabosse, P., \& Léonard, A. (2013). Review on fundamental aspect of application of drying process to wastewater sludge. Renewable and Sustainable Energy Reviews, 28, 29-43.

Bera, B., Saha, S., \& Bhattacharjee, S. (2020). Forest cover dynamics (1998 to 2019) and prediction of deforestation probability using binary logistic regression (BLR) model of Silabati watershed, India.Trees, Forest and People, 2, 100034.

Bligh, E.G. \& Dyer, W.J. (1959). A rapid method of total lipid extraction and purification. Canadian Journal of Biochemistry and Physiology , 37, 911-917.

Chakraverty, A. (1988). Theory of grain drying: post harvest technology of cereals, pulses and oilseeds. Oxford and IBH Publishing Co. Pvt. Ltd.

Chen, C., Chang, J., \& Lee, D. (2015). Dewatering and Drying Methods for Microalgae. Drying Technology , 33, 443-454.

Dreiseitl, S., \& Ohno-Machado, L. (2002). Logistic regression and artificial neural network classification models: a methodology review. Journal of Biomedical Informatics , 35, 352-359.

Guldhe, A., Singh, B., Rawat, I., Ramluckan, K. \& Bux, F. (2014). Efficacy of drying and cell disruption techniques on lipid recovery from microalgae for biodiesel production. Fuel , 128, 46-52.

Hosseinizand, H., Sokhansanj, S., \& Lim, C.J. (2018). Studying the drying mechanism of microalgae Chlorella vulgaris and the optimum drying temperature to preserve quality characteristics. Drying Technology , 36, 1049-1060.

Koley, S., Mathimani, T., Bagchi, S.K., Sonkar, S., \& Mallick, N. (2019). Microalgal biodiesel production at outdoor open and polyhouse raceway pond cultivations: A case study with Scenedesmus acuminatus using low-cost farm fertilizer medium. Biomass and Bioenergy , 120, 156-165.

Koley, S., Prasad, S., Bagchi, S.K., \& Mallick, N. (2017). Development of a harvesting technique for largescale microalgal harvesting for biodiesel production. RSC Advance, 7, 7227-7237.

Mahadevaswamy, M. \& Venkataraman, L.V. (1981). Microbial load in mass cultures of green algae Scenedesmus acutus and its processed powder. Journal of Biosciences , 3, 439-447.

O'Connell, D., Savelski, M., \& Slater, C.S. (2013). Life cycle assessment of dewatering routes for algae derived biodiesel processes. Clean Technologies and Environmental Policy , 15, 567-577. 
Oehrl, L.L., Hansen, A.P., Rohrer, C.A., Fenner, G.P., \& Boyd, L.C. (2001). Oxidation of phytosterols in a test food system. Journal of the American Oil Chemists' Society, 78, 1073-1078.

Rai, L. C., Mallick, N., Singh, J. B., \& Kumar, H. D. (1991). Physiological and biochemical characteristics of a copper tolerant and a wild type strain of Anabaena doliolum under copper stress. Journal of Plant Physiology 138, 68- 74.

Saleh, A.M., Hussein, L.A., Abdalla, F.E., El-Fouly, M.M., \& Shaheen, A.B. (1985). The nutritional quality of drum-dried algae produced in open door mass culture. Zeitschrift für Ernährungswissenschaft,24, 256-263.

Sethi, S.N. \& Naik, G.B. (2007). Wonder Gift of Nature:Spirulina . Fishing Chimes , 27, 16-17.

Shi, S., Li, H., Ding, X., \& Gao, X. (2020). Effects of household features on residential window opening behaviors: A multilevel logistic regression study. Building and Environment, 170, 106610.

Show, K.-Y., Lee, D.-J., \& Mujumdar, A. S. (2015). Advances and challenges on algae harvesting and drying. Drying Technology , 33, 386-394.

Soeder, C.J. \& Bolze, A. (1981). Sulphate deficiency stimulates the release of dissolved organic matter in synchronous culture ofScenedesmus obliquus . Physiologia Plantarum , 52, 233-238.

Sonkar, S., Deb, D., \& Mallick, N. (2020). Outdoor cultivation of the green microalga Chlorella minutissima in mini pond system under batch and fed-batch modes integrating low-dose sequential phosphate addition (LDSPA) strategy for biodiesel production. Biomassand Bioenergy , 138, 105596.

Villagracia, A.R.C., Mayol, A.P., Ubando, A.T., Biona, J.B.M.M., Arboleda Jr., N.B., David, M.Y., Tumlos, R.B., Lee Jr., H., Lin, O.H., Espiritu, R.A., Culaba, A.B., \& Kasai, H. (2016). Microwave drying characteristics of microalgae (Chlorella vulgaris ) for biofuel production. Clean Technologies and Environmental Policy , 18, 2441-2451.

Wahlen, B.D., Roni, M.S., Cafferty, K.G., Wendt, L.M., Westover, T.L., Stevens, D.M., \& Newby, D.T. (2017). Managing variability in algal biomass production through drying and stabilization of feedstock blends.Algal Research , 24, 9-18.

Widjaja, A., Chien, C.-C., \& Ju, Y.-H. (2009). Study of increasing lipid production from fresh water microalgae Chlorella vulgaris . Journal of the Taiwan Institute of Chemical Engineers, 40, 13-20.

Zepka, L.Q., Jacob-Lopes, E., Goldbeck, R., \& Queiroz, M.I. (2008). Production and biochemical profile of the microalgae Aphanothece microscopica Nägeli submitted to different drying conditions. Chemical Engineering and Processing , 47, 1305-1310.

Table 1 Variables used

\begin{tabular}{lll}
\hline Variables & Description & Type \\
\hline $\mathrm{X}_{1}$ & Residual moisture content & Input \\
$\mathrm{X}_{2}$ & Lipid yield & Input \\
$\mathrm{Y}$ & Poor or Good result =0 or 1 & Output \\
\hline
\end{tabular}

Table 2 Biomass and lipid yield of $C$. minutissima dried at $60{ }^{\circ} \mathrm{C}$ and bone-dried samples

\begin{tabular}{lll}
\hline Parameter & $\begin{array}{l}\mathbf{6 0}{ }^{\circ} \mathbf{C} \text { till to reach a constant } \\
\text { weight (Rai et al., 1991) }\end{array}$ & Bone drying $\left(\mathbf{1 0 3}{ }^{\circ} \mathbf{C}\right.$ for $\left.\mathbf{2 4} \mathbf{~ h}\right)$ \\
\hline $\begin{array}{l}\text { Biomass yield (g) } \\
\begin{array}{l}\text { Lipid yield }\left(\mathbf{m g ~ g}^{-1} \text { dry }\right. \\
\text { biomass) }\end{array}\end{array}$ & $2.51 \pm 0.06^{\mathrm{b}}$ & $2.29 \pm 0.08^{\mathrm{a}}$ \\
\hline
\end{tabular}


Note: Data presented are means $\pm \mathrm{SD}(\mathrm{n}=3)$.

Analysis was conducted row-wise and superscripted by different alphabets to denote significant diffrences $(\mathrm{P}$ $<0.05$, Duncan's new multiple range tests).

Table 3 Summary of the residual moisture content (\% wb) at a different temperature under varying drum speed

\begin{tabular}{llll}
\hline Drum speed $(\mathbf{r p m})$ & Drum surface temperature & Drum surface temperature & Drum surface temperature \\
\hline & $\mathbf{7 0} \pm \mathbf{2}^{\circ} \mathbf{C}$ & $\mathbf{8 0} \pm \mathbf{2}^{\circ} \mathbf{C}$ & $\mathbf{9 0} \pm \mathbf{2}{ }^{\circ} \mathbf{C}$ \\
0.1 & $41.4 \pm 2.7^{\mathrm{Ba}}$ & $5.2 \pm 1.6^{\mathrm{Aa}}$ & $4.6 \pm 1.1^{\mathrm{Aa}}$ \\
0.2 & $52.8 \pm 1.9^{\mathrm{Bb}}$ & $5.6 \pm 1.5^{\mathrm{Aa}}$ & $5.3 \pm 1.3^{\mathrm{Aa}}$ \\
0.3 & $63.7 \pm 2.6^{\mathrm{Bc}}$ & $8.9 \pm 2.8^{\mathrm{Aa}}$ & $6.1 \pm 1.5^{\mathrm{Aa}}$ \\
0.4 & $70.1 \pm 3.1^{\mathrm{Cd}}$ & $13.2 \pm 2.3^{\mathrm{Bb}}$ & $7.3 \pm 1.4^{\mathrm{Aa}}$ \\
0.5 & $78.5 \pm 2.8^{\mathrm{Ce}}$ & $20.7 \pm 3.4^{\mathrm{Bc}}$ & $11.5 \pm 1.5^{\mathrm{Ab}}$ \\
1.0 & $85.2 \pm 2.5^{\mathrm{Df}}$ & $73.8 \pm 4.2^{\mathrm{Cd}}$ & $48.2 \pm 3.7^{\mathrm{Bc}}$ \\
1.5 & $89.2 \pm 2.3^{\mathrm{Cfg}}$ & $85.5 \pm 4.6^{\mathrm{Ce}}$ & $74.1 \pm 3.9^{\mathrm{Bd}}$ \\
2.0 & $92.7 \pm 1.8^{\mathrm{Cg}}$ & $91.1 \pm 2.2^{\mathrm{Cf}}$ & $86.4 \pm 1.5^{\mathrm{Be}}$ \\
\hline
\end{tabular}

Note: Data presented are means $\pm \mathrm{SD}(\mathrm{n}=3)$.

Analysis was conducted row-wise (A-D) as well as column-wise (a-g) and superscripted by different alphabets to denote significant diffrences $(\mathrm{P}<0.05$, Duncan's new multiple range tests).

Table 4 Summary of lipid yield ( $\mathrm{mg} \mathrm{g}^{-1}$ of dry biomass) at different temperature with varying drum speed

\begin{tabular}{|c|c|c|c|c|}
\hline $\begin{array}{l}\text { Drum speed } \\
\text { (rpm) }\end{array}$ & $\begin{array}{l}\text { Drum surface } \\
\text { temperature }\end{array}$ & $\begin{array}{l}\text { Drum surface } \\
\text { temperature }\end{array}$ & $\begin{array}{l}\text { Drum surface } \\
\text { temperature }\end{array}$ & $\begin{array}{l}\text { Drum surface } \\
\text { temperature }\end{array}$ \\
\hline & $70 \pm 2{ }^{\circ} \mathrm{C}$ & $80 \pm 2{ }^{\circ} \mathrm{C}$ & $90 \pm 2{ }^{\circ} \mathrm{C}$ & $100 \pm 2{ }^{\circ} \mathrm{C}$ \\
\hline 0.1 & $72.1 \pm 3.2^{\mathrm{Ag}}(50.7)$ & $130.6 \pm 4.8^{\mathrm{Be}}(91.9)$ & $130.2 \pm 1.5^{\mathrm{Be}}(91.6)$ & $\begin{array}{l}128.5 \pm 5.8^{\mathrm{Be}} \\
(90.4)\end{array}$ \\
\hline 0.2 & $67.3 \pm 1.8^{\mathrm{Af}}(47.4)$ & $130.9 \pm 4.5^{\mathrm{Be}}(92.1)$ & $130.7 \pm 4.5^{\mathrm{Be}}(92.0)$ & $\begin{array}{l}128.3 \pm 4.4^{\mathrm{Be}} \\
(90.3)\end{array}$ \\
\hline 0.3 & $59.2 \pm 2.6^{\mathrm{Ae}}(41.7)$ & $131.3 \pm 3.1^{\mathrm{Be}}(92.4)$ & $131.0 \pm 6.2^{\mathrm{Be}}(92.2)$ & $\begin{array}{l}129.1 \pm 6.3^{\mathrm{Be}} \\
(90.9)\end{array}$ \\
\hline 0.4 & $54.1 \pm 4.2^{\mathrm{Ad}}(38.1)$ & $123.1 \pm 1.4^{\mathrm{Bd}}(86.6)$ & $132.2 \pm 3.4^{\mathrm{Be}}(93.0)$ & $\begin{array}{l}130.1 \pm 4.8^{\mathrm{Be}} \\
(91.6)\end{array}$ \\
\hline 0.5 & $51.4 \pm 3.1^{\mathrm{Acd}}(36.2)$ & $94.2 \pm 5.2^{\mathrm{Bc}}(66.3)$ & $124.1 \pm 2.1^{\mathrm{Cd}}(87.3)$ & $\begin{array}{l}133.3 \pm 5.4^{\mathrm{Be}} \\
(93.8)\end{array}$ \\
\hline 1.0 & $47.1 \pm 2.4^{\mathrm{Abc}}(33.1)$ & $53.3 \pm 2.5^{\mathrm{Ab}}(37.5)$ & $68.2 \pm 2.2^{\mathrm{Bc}}(48.0)$ & $73.2 \pm 6.6^{\mathrm{Bb}}$ \\
\hline 1.5 & $44.2 \pm 1.9^{\mathrm{Aab}}(31.1)$ & $46.1 \pm 2.1^{\mathrm{Aa}}(32.4)$ & $52.4 \pm 2.9^{\mathrm{Bb}}(36.9)$ & $55.4 \pm 5.7^{\mathrm{Ba}}(39.0)$ \\
\hline 2.0 & $39.4 \pm 2.1^{\mathrm{Aa}}(27.7)$ & $42.1 \pm 2.8^{\mathrm{ABa}}(29.6)$ & $45.3 \pm 1.1^{\mathrm{BCa}}(31.9)$ & $48.2 \pm 3.3^{\mathrm{Ca}}(33.9)$ \\
\hline
\end{tabular}

Note: Data presented are means $\pm \mathrm{SD}(\mathrm{n}=3)$.

Analysis was conducted row-wise (A-C) as well as column-wise (a-g) and superscripted by different alphabets to denote significant diffrences $(\mathrm{P}<0.05$, Duncan's new multiple range tests).

Data in the parentheses present the \% lipid recovery considering the lipid recovery from the bone-dried biomass as control, i.e., $100 \%$.

Table 5 Energy consumption at different temperature under various drum speed 


\begin{tabular}{llll}
\hline Drum surface temperature & Drum speed (rpm) & Drying time/ kg dry biomass $(\mathbf{h})$ & ${ }^{+}$Lipid recovery (\%) \\
\hline $80 \pm 2{ }^{\circ} \mathrm{C}$ & 0.1 & 3.10 & 91.9 \\
& 0.2 & 1.93 & 92.1 \\
& 0.3 & 1.49 & 92.4 \\
& 0.4 & 1.31 & 86.6 \\
& 0.5 & 1.17 & 66.3 \\
$90 \pm 2{ }^{\circ} \mathrm{C}$ & 0.1 & 3.27 & 91.6 \\
& 0.2 & 2.10 & 92.0 \\
& 0.3 & 1.71 & 92.2 \\
& 0.4 & 1.52 & 93.0 \\
$100 \pm 2{ }^{\circ} \mathrm{C}$ & 0.5 & 1.37 & 87.3 \\
& 0.1 & 3.43 & 89.7 \\
& 0.2 & 2.27 & 90.3 \\
& 0.3 & 1.88 & 90.9 \\
& 0.4 & 1.68 & 91.6 \\
& 0.5 & 1.57 & 93.8 \\
\hline
\end{tabular}

${ }^{+}$Lipid recovery of bone-dried biomass was considered as $100 \%$.

Table 6 Comparative assessment of drying time, lipid recovery, and energy consumption of oven-dried and tray-dried with drum-dried biomass at $80{ }^{\circ} \mathrm{C}$

\begin{tabular}{llll}
\hline & $\begin{array}{l}\text { Drying time/ kg dry } \\
\text { biomass (h) }\end{array}$ & Lipid recovery (\%) & $\begin{array}{l}\text { Energy consumption } \\
\text { (kWh/ kg dry } \\
\text { biomass) }\end{array}$ \\
\hline Oven drying $^{+}$ & 8.00 & 93.0 & 5.231 \\
Tray drying $^{++}$ & 6.00 & 93.0 & 11.227 \\
Drum drying & 1.49 & 92.4 & 7.328 \\
\hline
\end{tabular}

${ }^{+}$Bagchi et al. (2015), ${ }^{++}$Bagchi (2017)

\section{FIGURE LEGENDS}

FIGURE 1 Components of machine learning

FIGURE 2 Steps employed for machine learning

FIGURE 3 (A) Residual moisture content, (B) lipid yield, and (C) lipid recovery from C. minutissimabiomass at $70{ }^{\circ} \mathrm{C}$ in a single rotary drum dryer with variable speed.

Bone-dried biomass: Control

FIGURE 4 (A) Residual moisture content, (B)lipid yield, and (C) lipid recovery from C. minutissimabiomass at $80{ }^{\circ} \mathrm{C}$ in a single rotary drum dryer with variable speed.

Bone-dried biomass: Control

FIGURE 5 (A) Residual moisture content, (B)lipid yield, and (C) lipid recovery from C. minutissimabiomass at $90{ }^{\circ} \mathrm{C}$ in a single rotary drum dryer with variable speed.

Bone-dried biomass: Control

FIGURE 6 (A) Residual moisture content, (B)lipid yield, and (C) lipid recovery from C. minutissimabiomass at $100{ }^{\circ} \mathrm{C}$ in a single rotary drum dryer with variable speed. 
Bone-dried biomass: Control

FIGURE 7 (A) Distribution of raw data, (B) Division of data set using a decision boundary.

\section{Hosted file}

Figure.pdf available at https://authorea.com/users/369837/articles/488655-applicationof-machine-learning-for-development-of-a-drying-protocol-for-microalga-chlorellaminutissima-in-a-single-rotary-drum-dryer-for-biodiesel-production 